УДК 349.2

https://doi.org/10.34142/23121661.2019.30.05

orcid.org/0000-0002-7773-0402

(C) Ждан М.Д., 2019

\author{
М.Д. Ждан
}

\title{
ЩОДО ПРОБЛЕМИ ПРАВОВОГО РЕГУЛЮВАННЯ ВІДСТОРОНЕННЯ ПРАЦІВНИКА ВІД РОБОТИ
}

\author{
M. Zhdan \\ REGARDING THE PROBLEM \\ OF LEGAL REGULATION \\ OF DISMISSAL OF AN EMPLOYEE
}

\begin{abstract}
Анотація. Метою наукової статті $є$ визначення мети відсторонення працівника від роботи та підстав такого відсторонення. Зазначено, що відсторонення від роботи завжди $\epsilon$ проміжною стадією, яка закінчиться або поновленням дії трудового договору і поверненням на попередню роботу, або зміною трудового договору, або, навіть, його припиненням. Обгрунтовується, що, при відстороненні від роботи основною метою є захист інтересів власника та працівників, а також попередження можливих порушень правил охорони праці та трудової дисципліни. Запропоновано доповнити чинне законодавство новою підставою відсторонення працівника від роботи.
\end{abstract}

Ключові слова: відсторонення працівника від роботи; право на працю; трудовий договір; мета відсторонення працівника від роботи; підстави відсторонення від роботи.

Аннотация. Целью научной статьи является определение цели отстранения работника от работы и оснований такого отстранения. Отмечается, что отстранение от работы всегда является промежуточной стадией, которая заканчивается или возобновлением действия трудового договора и возвращением на прежнюю работу, или изменением трудового договора, или даже его прекращением. Обосновывается, что при отстранении от работы основной целью является защита интересов собственника и работников, а также избежание возможных нарушений правил охраны труда и трудовой дисциплины. Предложено дополнить действующее законодательство новым основанием отстранения работника от работы.

Ключевые слова: отстранение работника от работы; право на труд; трудовой договор; цель отстранения работника от работы; основания отстранения от работы.

Abstract. The purpose of the scientific article is to determine the purpose of dismissal of the employee and the reasons for such removal. It is proved that today neither current legislation, nor jurisprudence, nor science contain a single well-considered vision of the place of exclusion in the labor law system. It is noted that termination of work is always an intermediate stage, which will end either with the renewal of the employment contract and return to previous work, or with the change of the employment contract, or, even, its termination. It is substantiated that, upon 
dismissal from work, the main purpose is to protect the interests of the owner and employees, as well as to prevent possible violations of the rules of labor and labor discipline. Based on the analysis of the current legislation, it has been found that there are a lot of entities that have the right to initiate dismissal. By organizing data on the legal capacity of subjects to initiate dismissal, they are divided into three groups: a) entities that make the decision to dismiss and implement it; $b$ ) those requiring mandatory dismissal; c) those who raise the issue of dismissal. It is proposed to supplement the current legislation with a new reason for dismissal of an employee.

Key words: dismissal of employee; the right to work; employment contract; the purpose of removing the employee from work; subjects who may initiate the question of dismissal of the employee; protection of the interests of the owner and employees; removal from work.

Роль законодавства про працю визначається ефективністю регулювання трудових відносин. У зв'язку з цим основна мета трудового законодавства встановлення державних гарантій трудових прав і свобод громадян, створення сприятливих умов праці, захисту прав та інтересів робітників і роботодавців. У сучасних умовах особливого значення набуває проблема забезпечення прав працівників як державою, так і конкретним роботодавцем.

Реформа українського трудового законодавства, що триває із часів отримання Україною незалежності, незважаючи на неодноразові спроби розробки та прийняття нового кодифікованого акту - Трудового кодексу України, i досі не добігає свого кінця [1, с. 20]. 3 огляду на це ніяких сумнівів не викликає необхідність проведення наукових досліджень щодо проблем правового регулювання усіх категорій трудового права, зокрема проблеми правового регулювання відсторонення працівника від роботи.

На превеликий жаль, питанню щодо відсторонення від роботи в науці трудового права не приділяється достатньої уваги. На сьогоднішній день можна назвати лише окремі наукові праці, в яких мова йде безпосередньо про відсторонення працівника від роботи, зокрема, це праці М.О. Кабаченка [2], Л.В. Межевської [3], В.Г. Петрова [4], С.М. Прилипка та О.М. Ярошенка [5], В.О. Процевського [6], Д.В. Трубіцина [7] та інших науковців.

Відсторонення працівника від роботи - це призупинення виконання ним своїх трудових обов'язків за рішенням уповноважених на це компетентних органів, що, як правило, відбувається з одночасним призупиненням виплати йому заробітної плати, і це та нетипова дія, з якою роботодавці стикаються не так часто.

У межах даного дослідження відсторонення від роботи нас цікавить остільки, оскільки на законодавчому рівні не визначено мету відсторонення та його підстави. Зазначимо, що актуальність вищезазначеного питання проявляється і в тому, що на сьогодні ні чинне законодавство, ні судова практика, ні наука не містять єдиного виваженого висновку щодо місця відсторонення у системі трудового права. Зокрема, сучасні провідні науковці у сфері трудового права C.М. Прилипко та О.М. Ярошенко прямо не зазначають про своє бачення місця відсторонення у системі трудового права, однак розміщують у 
підручнику «Трудове право України» у розділі, де характеризується припинення трудового договору [5, с. 374]. Львівський колектив авторів підручника «Трудове право України» за ред. П.Д. Пилипенка також прямо не висловлює своєї позиції щодо місця відсторонення, однак розміщує його у розділі, присвяченому зміні умов трудового договору [8, с. 265-270]. Водночас В.О. Процевський визначив, що відсторонення $\epsilon$ самостійним правовим явищем і не може охоплюватися змістом понять «зміна трудового договору» чи «припинення трудового договору» [6, с. 5-26]. Дійсно, при відстороненні має місце призупинення виконання працівником своїх трудових обов'язків за рішенням уповноважених на це компетентних органів, що, як правило, відбувається з одночасним призупиненням виплати йому заробітної плати. А тому визнати відсторонення зміною трудового договору не можна: умови трудового договору не змінюються, він призупиняється (адже робота не виконується внаслідок законного недопущення працівника роботодавцем до виконання його трудової функції), і його умови, таким чином, також призупиняються. Припиненням трудового договору відсторонення також вважати не можна, адже трудовий договір не припиняється - працівника не звільняють 3 роботи, не видають наказу про його звільнення, він лише тимчасово до роботи не допускається. Слід також погодитися із В.О. Процевським, що відсторонення від роботи є тим правовим явищем, яке може передувати зміні умов трудового договору [6, с. 95]. У зв'язку з цим можна стверджувати, що відсторонення $є$ правовою причиною, а зміна трудового договору - правовим наслідком відсторонення від роботи, яка повинна відбуватися за усіма правилами чинного законодавства, зокрема щодо надання згоди на зміну трудового договору працівником. До речі, він також слушно зазначає, що «відсторонення від роботи саме по собі не може служити юридичним фактом для виникнення нових правовідносин. Воно - $є$ лише результат реалізації норм права уповноваженими органами або посадовими особами в рамках нових охоронних правовідносин» [6, с. 46]. Таким чином, можна констатувати, що відсторонення від роботи - це завжди тимчасовий захід, проміжна стадія, яка закінчується або поновленням дії трудового договору і поверненням до попередньої роботи, або зміною трудового договору, а іноді - його припиненням. Але відразу виникає запитання, навіщо існує такий «підінститут», і яка його мета?

Аналіз чинного Кодексу законів про працю України (далі - КЗпП України) [9], а саме статті 46 КЗПП - не дає відповіді на дане запитання. Означена норма надає нам можливість лише чітко визначити суб'єкта, який може реалізувати своє право на відсторонення, та в яких випадках це можливо здійснити. Вищезазначеним суб'єктом виступає власник або уповноважений ним орган. Необхідно наголосити і про безумовно цивілізаційний підхід до особистості працівника, закладений у законодавстві, який відображає прагнення до встановлення балансу інтересів сторін трудового договору, адже роботодавець повинен повідомити працівника про причини і факт відсторонення. 
Вважаємо за необхідне зосередити увагу й на тому, що суб'єктів, які наділені правом ініціювати відсторонення від роботи, у чинному законодавстві визначено також достатньо. Вітчизняні науковці, зокрема В.О. Процевський, систематизувавши дані щодо правових можливостей таких суб'єктів ініціювання відсторонення від роботи, розділив їх умовно на три групи:

а) суб'єкти, які ухвалюють рішення про відсторонення від роботи і самі його реалізують;

б) ті, які вимагають обов'язкового відсторонення від роботи;

в) ті, які ставлять питання про відсторонення від роботи [6, с. 52-53].

Проаналізувавши чинне законодавство про працю в республіках колишнього Радянського Союзу, можна констатувати, з одного боку, збереження значного числа юридичних норм і конструкцій, котрі існували в радянський період і регулювали конкретні питання трудових відносин, а з іншого - майже повна відмова від ідеологічних догм соціалізму й пропагандистських декларацій, якими відзначалися радянські закони. Скасовано або видозмінено багато норм і положень колишнього трудового законодавства, що суперечать основним принципам ринкової економіки, демократичним правам і свободам людини. Сучасне правотворення відрізняється прагненням врахувати позитивний досвід правової регламентації суспільних відносин, у тому числі і трудових, у зарубіжних країн, зокрема, щодо відсторонення працівника від роботи [3, с. 108].

Так, норми трудового законодавства Російської Федерації досить докладно регулюють підстави й порядок відсторонення працівника від роботи. Стаття 76 Трудового кодексу РФ від 30 грудня 2001 р., яка регламентує порядок відсторонення від роботи, розміщена в главі «Зміна трудового договору» [10]. У Трудовому кодексі РФ, вважаємо, норма про відсторонення від роботи справедливо розташована в главі «Зміна трудового договору» перед главою «Припинення трудового договору», оскільки вона не припиняє трудового договору, а лише змінює на певний час його деякі умови. Відповідно до ст. 76 ТК РФ роботодавець зобов'язаний відсторонити від роботи (не допускати до роботи) працівника, який: з'явився на роботі в стані алкогольного, наркотичного або іншого токсичного сп'яніння; не пройшов у встановленому порядку навчання й перевірку знань і навичок щодо охорони праці; не пройшов у встановленому порядку обов'язковий медичний огляд (обстеження), а також обов'язковий психіатричний огляд у випадках, передбачених федеральними законами й іншими нормативними правовими актами Російської Федерації; при виявленні відповідно до медичного висновку, виданого у порядку, встановленому федеральними законами й іншими нормативними правовими актами Російської Федерації, протипоказань для виконання працівником роботи, обумовленої трудовим договором; у випадку призупинення дії на строк до двох місяців спеціального права працівника (ліцензії, права на управління транспортним засобом, права на носіння зброї, іншого спеціального права) відповідно до федеральних законів й інших нормативних правових актів 
Російської Федерації, якщо це спричиняє неможливість виконання працівником обов'язків за трудовим договором і якщо неможливо перевести працівника за його письмової згоди на іншу наявну в роботодавця роботу (як вакантну посаду або роботу, котра відповідає кваліфікації працівника, так і вакантну нижчу посаду), що працівник може виконувати 3 урахуванням його стану здоров'я тощо.

Редакції статей кодифікованих трудових законів країн СНД, що регулюють питання про відсторонення від роботи, відрізняються достатніми гарантіями реалізації й здійснення права на працю, оскільки правовий припис сформульовано таким чином, що він забороняє відстороняти від роботи, за винятком випадків, передбачених у законодавстві про працю.

Аналізуючи закони про працю окремих країн СНД, необхідно зазначити, що редакції статей законів про працю, що регламентує питання відсторонення від роботи, передбачають одну єдину підставу відсторонення - появу працівника на роботі в стані алкогольного, наркотичного або токсичного сп'яніння $[3$, c. 111$]$.

Наприклад, у ст. 54 Трудового кодексу Республіки Таджикистан від 15 травня 1997 р. [11] міститься саме така підстава відсторонення від роботи.

Найбільш невдалим, на наш погляд, є формулювання статті, котра регламентує питання відсторонення від роботи, що міститься в Кодексі законів про працю Республіки Молдова від 28 березня 2003 р. (ст. 43), а саме, законодавець скоротив положення статті до однієї пропозиції: «відсторонення працівника від роботи (посади) може провадитися тільки у випадках, передбачених законодавством» [12].

При цьому зазначимо, що нормотворча діяльність у сфері законодавства про працю інших суверенних держав - колишніх союзних республік, таких, наприклад, як Республіка Узбекистан, Республіка Білорусь, Республіка Азербайджан змінили й обновили норми статей про відсторонення від роботи.

Так, у статті 113 Трудового кодексу республіки Узбекистан від 21 грудня 1995 р. [13] законодавець досить чітко викладає повноваження роботодавця щодо відсторонення працівника від роботи. Вказана норма містить пункт про те, що у випадку відхилення працівника від проходження обов'язкового медичного огляду або невиконання ним рекомендацій, видаваних лікарськими комісіями щодо результатів проведення обстежень, роботодавець вправі не допускати його до роботи. Крім того, стаття була доповнена нормою про покладання на роботодавця обов'язку по відшкодуванню заподіяної працівникові шкоди за незаконне відсторонення його від роботи.

На наш погляд, таке нововведення - про включення положення про відповідальність роботодавця перед працівником за незаконне відсторонення від роботи в статтю, котра регламентує питання відсторонення працівника від роботи, представляється досить цікавим, хоча в трудовому законодавстві України застосовується інший підхід, а саме відповідальність посадових осіб - 
роботодавців за порушення законодавства про працю й охорону праці, регламентується ст. 41 Кодексу України про адміністративні правопорушення від 7 грудня 1984 р. [14]. Вищезазначені дії спричиняють накладення штрафу на посадових осіб підприємств, установ і організацій незалежно від форми власності та громадян - суб'єктів підприємницької діяльності від 30 до 100 неоподатковуваних мінімумів доходів громадян. У зв’язку з цим можна зробити висновок, що у випадку, якщо роботодавець не виконав покладений на нього трудовим законодавством обов'язок по відстороненню працівника від роботи, він буде притягнутий до адміністративної відповідальності. При цьому, якщо роботодавець незаконно відсторонив працівника від роботи, то він зобов'язаний відшкодувати працівникові в повному розмірі неотриманий ним заробіток.

У Республіці Білорусь у 1999 р. був прийнятий новий Трудовий кодекс, який набув чинності 31 січня 2000 р. [15]. При порівнянні норм, котрі регулюють відсторонення від роботи в ТК Республіки Білорусь (ст. 49) і КЗПП України (ст. 46), можна констатувати, що в зазначених статтях є схожі підстави відсторонення від роботи - це поява працівника на роботі в стані алкогольного, наркотичного або іншого токсичного сп'яніння; непроходження працівником перевірки знань з охорони праці; непроходження працівником медичного огляду у випадках і в порядку, передбачених законодавством.

Необхідно зазначити, що у ТК Республіки Білорусь міститься норма, відповідно до якої «наймач має право відсторонити від роботи працівника, затриманого за місцем роботи в момент здійснення крадіжки до набуття законної сили вироку суду або постанови органа, у компетенцію якого входить накладення адміністративного стягнення» [15].

На наш погляд, найбільш правильна, порівняно 3 іншими трудовими законодавчими актами країн-учасниць СНД, позиція законодавця Азербайджанської республіки. Трудовий кодекс Азербайджанської Республіки, затверджений 1 лютого 1999 р. [16], найбільш повно й докладно регламентує норми про відсторонення від роботи. Стаття 62 ТК Азербайджанської республіки також як і статті, котрі регулюють порядок відсторонення від роботи в законах про працю інших союзних держав, поміщена в розділ «Трудовий договір», але в той же час вона відрізняється від розглянутих вище. У першому пункті цієї статті зазначена мета застосування даної норми трудового права, а саме: «роботодавець відстороняє від роботи з метою захисту інтересів власника й працівників, для попередження можливих порушень правил охорони праці й для забезпечення трудової дисципліни» [16].

Жоден інший нормативно-правовий акт про працю колишніх союзних республік не містить у собі мети застосування норми про відсторонення від роботи. Вважаємо, що визначення й уточнення цілей застосування розглянутої норми $є$ важливим чинником для правозастосовної практики, що сприяє з'ясуванню ii змісту, недопущенню ii ігнорування або фактів незаконного відсторонення від роботи. 
Крім того, у ст. 62 ТК Азербайджанської Республіки перераховуються підстави відсторонення від роботи, які, на відміну від формулювань, котрі містяться в законах про працю інших колишніх союзних республік, найдокладніше регламентують, у яких випадках роботодавець має право відстороняти працівника від роботи:

a) 3 появою працівника на роботі в нетверезому стані після прийняття ним алкогольних напоїв, наркотичних, токсичних й інших отруйних речовин, а також при знаходженні в нетверезому стані після прибуття на роботу, прийнявши ці напої або речовини на робочому місці;

б) при відхиленні працівника від обов'язкового медичного обстеження у випадках, визначених ст. 226 ТК Азербайджанської республіки або при недотриманні ними рекомендацій, виданих лікарськими комісіями на підставі результатів проведеного обстеження;

в) при здійсненні працівником протягом робочого часу безпосередньо на місці роботи адміністративних правопорушень або суспільно-небезпечних дій, що мають злочинний характер, підтверджуваних висновком відповідного компетентного органу [16].

Остання підстава відсторонення працівника від роботи наявна лише в ТК Азербайджанської республіки. Вбачається, що даною підставою відсторонення працівника від роботи було б доцільним доповнити й ст. 46 КЗпП України (або відповідну статтю проекту ТК), оскільки в цей час не зрозуміло, як повинен діяти роботодавець у випадку, коли працівник, наприклад, здійснив крадіжку на роботі або своїми неправомірними діями привів у непридатний стан устаткування. Вважаємо, що в даному випадку в роботодавця повинна бути можливість відсторонити від роботи такого працівника до з'ясування всіх обставин справи. Після розгляду питання по суті до працівника або можуть бути застосовані заходи дисциплінарного стягнення, аж до звільнення, або він може бути допущений до роботи.

Проаналізувавши позитивні сторони розглянутих правових конструкцій трудового законодавства Білорусі й Азербайджану, пропонуємо доповнити ст. 46 КЗпП України новою підставою відсторонення працівника від роботи: роботодавець вправі відсторонити від роботи (не допускати до роботи) працівника при здійсненні працівником протягом робочого часу безпосередньо на місці роботи адміністративних правопорушень або суспільно-небезпечних дій, що мають злочинний характер, підтверджуваних висновком відповідного повноважного органу.

Отже, на підставі проведеного дослідження пропонуємо включити до проекту ТК України статтю наступного змісту, а чинну ст. 46 КЗпП України викласти наступним чином:

«Роботодавець відстороняє працівника від роботи з метою захисту інтересів власника й працівників, для попередження можливих порушень правил охорони праці й для забезпечення трудової дисципліни. 
Відсторонення працівників від роботи власником або уповноваженим ним органом допускається у разі: появи на роботі в нетверезому стані, у стані наркотичного або токсичного сп'яніння; відмови або ухилення від обов'язкових медичних оглядів, навчання, інструктажу і перевірки знань 3 охорони праці та протипожежної охорони; при здійсненні працівником протягом робочого часу безпосередньо на місці роботи адміністративних правопорушень або суспільно-небезпечних дій, що мають злочинний характер, підтверджуваних висновком відповідного повноважного органу; в інших випадках, передбачених законодавством».

\section{Література}

1. Коваленко О.О. Окремі проблеми свободи волі сторін трудового договору при відстороненні працівника від роботи. Збірник наукових пращьь Харківського національного педагогічного університету імені Г. С. Сковороди «Право». 2016. Вип. 25. С. 19-25; 2. Кабаченко М.О. Відсторонення від роботи працівника у трудовому праві: деякі актуальні питання. Актуальні проблеми трудового права і права соціального забезпечення: тези доповідей та наукових повідомлень учасників $\mathrm{V}$ Міжнародної науково-практичної конференції, Харків, 27-28 вересня 2013 р. / за ред. В. В. Жернакова. Х.: Право, 2013. С. 435-437; 3. Межевська Л.В. Правове регулювання відсторонення від роботи осіб, які виконують функції держави: дис. ... канд. юрид. наук : 12.00.05. Кривий Ріг, 2017. 182 с.; 4. Петров В.Г. Зміст трудових правовідносин під час відсторонення працівника від роботи: автореф. дис. ... канд. юрид. наук : 12.00.05. Луганськ, 2011. 20 с.; 5. Прилипко С.М., Ярошенко О.М. Трудове право України: підручник; 3-тє вид., переробл. і доп. Харків : Видавництво «ФІНН», 2010. 752 с.; 6. Процевський В.О. Проблеми правового регулювання відсторонення від роботи: монографія. Х., 2006. 144 с.; 7. Трубіцин Д.В. Відсторонення працівника від роботи : теорія та практика: автореф. дис. ... канд. юрид. наук : 12.00.05. Луганськ, 2011. - 24 с.; 8. Пилипенко П.Д., Бурак В.Я., Козак 3.Я. та ін. Трудове право України: академічний курс: підруч. для студ. юрид. спец. вищ. навч. закл.; 2-е вид., перероб. і доп. К.: Видавничий Дім «Ін Юре», 2006. 544 с.; 9. Кодекс законів про працю України / Верховна Рада УРСР : Кодекс України; Закон від 10.12.1971 № 322-VIII. URL: http://zakon3.rada.gov.ua/laws/show/322-08/page5 (дата звернення: 27.04.2019). - Назва 3 екрану; 10. Трудовий кодекс РФ от 30.12.2001 г. URL: http://www.consultant.ru/popular/ tkrf/14_16.html\#p1413; 11. Трудовой кодекс Республики Таджикистан от 15.05.1997 г. URL: http://www.base.spinform.ru; 12. Трудовой кодекс Республики Молдова от 28.03.2003 г., №154-XV. URL: http://www.base.spinform.ru; 13. Трудовой кодекс Республіки Узбекистан от 21.12.1995 г. URL: http://www.base.spinform.ru; 14. Кодекс України про адміністративні правопорушення / Верховна Рада УРСР : Кодекс України; Закон від 7 грудня 1984 р. № 8073-X. URL: http://zakon3.rada.gov.ua/laws/show/322-08/page5 (дата звернення: 26.04.2019). - Назва з екрану; 15. Трудовой кодекс Республики Беларусь от 26.07.1999 г., №296-3. URL: http://www.base.spinform.ru; 16. Трудовой кодекс Азербайджанской Республики от 01.02.1999 г. URL: http://www.base.spinform.ru 